\title{
Upland rice agronomic performance in response to different doses and sources of nitrogen
}

\author{
Tácio Peres da Silva ${ }^{1}$, Douglas Goulart Castro ${ }^{1}$, Laís Moretti Tomé ${ }^{1}$, Marco Renan Félix ${ }^{2}$, Antônio Rosário \\ Neto ${ }^{1}$, Flavia Barbosa Silva Botelho ${ }^{1}$ \\ ${ }^{1}$ Universidade Federal de Lavras - UFLA, Lavras, MG. ${ }^{2}$ Universidade Estadual Paulista - UNESP, SP. E-mail: \\ douglasgoulartcastro@gmail.com
}

\begin{abstract}
The aim of the present study was to evaluate the response of different doses and sources of nitrogen (N) on agronomic characteristics in upland rice as well as the climatic and environmental influence on nitrogen fertilization results. The experiments were conducted in the University of Lavras, during 2015/2016 and 2016/2017 crop seasons, the plots consisted of 4 lines of 3 linear meters, with spacing among rows of 35 $\mathrm{cm}$ and a useful plot of $4.2 \mathrm{~m}^{2}$. The experimental design was a randomized complete block design with three replications in a $4 \times 4 \times 2$ factorial design. The factor dose consisted in 0, 50, 100 e $200 \mathrm{~kg} \mathrm{ha}^{-1} \mathrm{~N}$ and the factor sources consisted in ammonium nitrate, ammonium sulphate, urea and polycote, totaling 16 treatments. The characteristics evaluated were plant height, grain yield, grain chalkness, 1000 grains weight and yield. It was concluded that the addiction of doses and $\mathrm{N}$ sources did not change the agronomic performance of the upland rice crop. There is an influence of the environment on the responses of plants to nitrogen application, being observed different results in different crop seasons.
\end{abstract}

Keywords: Oryza sativa, Mineral nutrition, plant development

\section{Desempenho agronômico de arroz de terras altas em resposta a diferentes doses e fontes de nitrogênio}

\section{Resumo}

O objetivo do presente estudo foi avaliar a resposta de diferentes doses e fontes de nitrogênio (N) às características agronômicas do arroz de terras altas, bem como a influência climática e ambiental nos resultados da fertilização nitrogenada. Os experimentos foram conduzidos na Universidade de Lavras, nas safras 2015/2016 e 2016/2017, as parcelas consistiram em 4 linhas de 3 metros lineares, com espaçamento entre linhas de $35 \mathrm{~cm}$ e uma parcela útil de $4,2 \mathrm{~m}^{2}$. O delineamento experimental foi o de blocos casualizados, com três repetições, em esquema fatorial $4 \times 4 \times 2$. As doses consistiram em 0, 50, 100 e 200 $\mathrm{kg} \mathrm{ha}^{-1} \mathrm{~N}$ e as fontes de nitrogênio consistiram em nitrato de amônio, sulfato de amônio, uréia e policote, totalizando 16 tratamentos. As características avaliadas foram altura da planta, produtividade de grãos, giz de grãos, peso de 1000 grãos e produtividade. Concluiu-se que as diferentes doses e fontes de $\mathrm{N}$ não alteraram o desempenho agronômico da cultura do arroz de terras altas. Existe uma influência do ambiente nas respostas das plantas à aplicação de nitrogênio, sendo observados diferentes resultados em diferentes épocas da colheita.

Palavras-chave: Oryza sativa, nutrição mineral, desenvolvimento de plantas

\section{Introduction}

Rice (Oryza sativa L.) occupies the fourth position among the most produced grains in the world, behind only soybeans, wheat and corn. Of the total produced, about 740 million tons, $85 \%$ are directed to human consumption and are part of the diet of more than half of the world's population (FAOSTAT, 2016).

Plants are autotrophic and to properly meet their demands, there is a need for nutrients, which 
participate directly and indirectly in the synthesis processes of sugars, carbohydrates, proteins, and lipids (TAIZ; ZEIGER, 2013). Thus, better plant mineral nutrition is directly associated with better plant development, and regarding cultivated plants, it provides a better grain yield and consequently, satisfactory final production (EPSTEIN; BLOOM, 2006).

The functions of $\mathrm{N}$ in the plant are diverse, being the element required in greater quantity by most plants, including upland rice. Biochemically $\mathrm{N}$ has functions such as constituent of amino acids, amides, proteins, nucleic acids, nucleotides, coenzymes, hexoamines, among others (MEDEIROS et al., 2007).

Fidelis et al. (2012) worked with seven rice cultivars varying $\mathrm{N}$ rates from 20 to $120 \mathrm{~kg} \mathrm{ha}^{-1}$, concluding that higher doses influenced higher plant heights and delayed flowering of all cultivars, however, positively affected one cultivar in the grain yield characteristic. While Hernandes et al. (2010), working with $\mathrm{N}$ rates ranging from 0 to 200 $\mathrm{kg} \mathrm{ha}^{-1}$, as well as using three distinct $\mathrm{N}$ sources, obtained higher grain yield by applying $122 \mathrm{~kg} \mathrm{ha}^{-1}$ of $\mathrm{N}$, but there was no difference between $\mathrm{N}$ sources.

Basic fertilization in all cultivated crops is made using nitrogen $(\mathrm{N})$, potassium $(\mathrm{K})$ and phosphorus ( $\mathrm{P})$. For $\mathrm{K}$ and $\mathrm{P}$ we have soil analysis as support for interpretation, and thus, correct recommendation. In the case of $\mathrm{N}$, the value of soil organic matter is taken into account, but this recommendation is made indirectly. The ideal for $\mathrm{N}$ is the regional experimentation with different doses, sources and times of application in each crop, and the same should be done in upland rice (EMBRAPA, 2018). However, there are several nitrogen fertilizer options on the market, each with its own advantages and disadvantages. Experiments in each crop are needed to answer which source and dose to use. Therefore, this paper aimed to evaluate the response of the application of different doses and $\mathrm{N}$ source on agronomic characteristics in upland rice.

\section{Material and Methods}

The experiments were conducted in LavrasMG, Brazil, latitude $21^{\circ} 14^{\prime} \mathrm{S}$, longitude $44^{\circ} 59^{\prime} \mathrm{W}$, altitude $919 \mathrm{~m}$ and climate Cwa (humid subtropical climate). The soil of the area is classified as RedYellow Latosol.

In both crop seasons, conventional tillage system was performed. An upland rice elite line, named 1509, from the VCU (Value of Cultivation and Use) trial of the upland rice breeding program of the University of Lavras (UFLA) were evaluated.

According to soil analysis, it was not necessary to perform cultural treatments aimed at soil acidity correction. Fertilizers were applied based on soil analysis following the recommendations described in the publications of Villar (2007) and Sousa and Lobato (2004). The expected yield was $4 t$ $\mathrm{ha}^{-1}$, with an average topdressed application of 450 $\mathrm{kg}$ of 04-14-08 in the planting of both crop seasons.

The plots consisted of 4 lines of 3 linear meters, seeding density was 80 seeds per linear meter with spacing among rows of $35 \mathrm{~cm}$, and a useful plot of $4.2 \mathrm{~m}^{2}$. The experimental design was a randomized complete block design with three replications in a $4 \times 4 \times 2$ factorial design. The dose consisted in $0,50,100$ e $200 \mathrm{~kg} \mathrm{ha}^{-1}$ of $\mathrm{N}$ and the sources consisted in ammonium nitrate, ammonium sulphate, urea and polycote, totaling 32 treatments.

Due to the fact that each source of $\mathrm{N}$ contains different concentrations of $\mathrm{N}$, urea $(45 \%$ $\mathrm{N})$, ammonium sulphate $(21 \% \mathrm{~N})$, ammonium nitrate $(33 \% \mathrm{~N})$ and polycote $(46 \% \mathrm{~N})$, these values were taken into account during the conversion of application of $\mathrm{N}$ doses. It was also converted the $\mathrm{N}$ doses, which are in hectares, to linear meter for fertilizer weighing and subsequent application in the treatments. Fertilizer application in the 2015/2016 crop season occurred at 25 days after the emergence (DAE) and at 29 DAE during the 2016/2017 crop season.

The water conditions in both years were considered adequate, and supplementation through sprinkler irrigation was made in periods of drought. For weed control, the same protocol was used in both crops, applications of pre-emergence ( 0 days after planting [DAP]) Pendimenthalin (Herbadox ${ }^{\circledR}$ ) and Metsulfuron-methyl $\left(\mathrm{Ally}^{\circledR}\right)$ in post-emergence (20 DAE). No applications of fungicides, insecticides and foliar fertilizers were performed in any of the experiments.

The phenotypic characteristics were evaluated. Plant height: from ground level to the end of the panicle of the main stem (five plants per plot randomly chosen); Grain yield: in grams per plot adjusted for $\mathrm{kg} \mathrm{ha}^{-1}$, referring to the plot useful area (two central lines); 100 grain weight: repeated eight times, being the obtained average multiplied by 10 , according to the rules for seed analysis (BRASIL, 2009); Yield: percentage of whole grains resulting from the processing of paddy rice; Grain chalkiness: counting of grain chalkiness in a 100 grain sample, with replications. 
The joint analysis was performed after verifying the normality of the data. The analyses were performed using the statistical software SISVAR $^{\circledR}$ (FERREIRA, 2011). For significant results, the Scott and Knott test was performed.

\section{Results and Discussion}

The experimental accuracy was evaluated by the coefficient of variation (CV), the CV was lower than $20 \%$ for almost all characteristics, indicating a good experimental accuracy (PIMENTEL-GOMES, 2009). The characteristic plant height is considered very important in experiments of the most varied crops, including upland rice, because plants with over height tend to lodge more easily, making the harvest difficult and causing losses in yield and quality of grains. Using the joint analysis for height character, there was no significant difference between the doses and types of fertilizers used. It was obtained significance only for $\mathrm{N}$ doses (ND) $\mathrm{x}$ Crop season (CS) at $5 \%$ probability (Table 1).

Table 1. Joint variance analysis for the characters' grain yield $\left(\mathrm{kg} \mathrm{ha}^{-1}\right)$, plant height $(\mathrm{cm})$, yield $(\%), 1000$ grain weight (grams) and chalkiness (\%).

\begin{tabular}{|c|c|c|c|c|c|c|}
\hline SV & DF & $\begin{array}{c}\mathrm{Pr}>\mathrm{Fc} \\
\text { (Grain Yield) }\end{array}$ & $\begin{array}{c}\text { Pr }>\text { Fc } \\
\text { (Height) }\end{array}$ & $\operatorname{Pr}>\mathrm{Fc}$ (Yield) & $\begin{array}{c}P r>F c \\
\text { (1000 grain) }\end{array}$ & $\begin{array}{c}\mathrm{Pr}>\mathrm{Fc} \\
\text { (Chalkiness) }\end{array}$ \\
\hline N Doses (N. D) & 3 & $0,690^{\mathrm{ns}}$ & $0,000^{\text {ns }}$ & $0,423^{\mathrm{ns}}$ & $0,924^{\mathrm{ns}}$ & $0,224^{\mathrm{ns}}$ \\
\hline N Source (N. S) & 3 & $0,702^{\mathrm{ns}}$ & $0,094^{\mathrm{ns}}$ & $0,788^{\text {ns }}$ & $0,002^{* *}$ & $0,337^{\mathrm{ns}}$ \\
\hline Crop season (C.S) & 1 & $0,106^{\text {ns }}$ & $0,503^{\mathrm{ns}}$ & $0,000^{* *}$ & $0,000^{* *}$ & $0,000^{* *}$ \\
\hline N.D $\times$ N.S & 9 & $0,114^{\mathrm{ns}}$ & $0,358^{\mathrm{ns}}$ & $0,092^{\text {ns }}$ & $0,450^{\text {ns }}$ & $0,635^{\text {ns }}$ \\
\hline N.D $\times$ C.S & 3 & $0,343^{\mathrm{ns}}$ & $0,044^{*}$ & $0,230^{\mathrm{ns}}$ & $0,965^{\mathrm{ns}}$ & $0,269^{\text {ns }}$ \\
\hline N.S $\times$ C.S & 3 & $0,948^{\mathrm{ns}}$ & $0,743^{\mathrm{ns}}$ & $0,034^{*}$ & $0,613^{\mathrm{ns}}$ & $0,261^{\mathrm{ns}}$ \\
\hline N.D $\times$ N.S $\times$ C.S & 9 & $0,116^{\text {ns }}$ & $0,887^{\text {ns }}$ & $0,401^{\text {ns }}$ & $0,321^{\text {ns }}$ & $0,391^{\mathrm{ns}}$ \\
\hline Blocks/C.S & 2 & $0,003^{* *}$ & $0,001^{* *}$ & $0,270^{\text {ns }}$ & $0,003^{* *}$ & $0,029^{*}$ \\
\hline Error & 62 & & & & & \\
\hline CV (\%) & & 24,09 & 5,37 & 2,55 & 5,51 & 4,10 \\
\hline
\end{tabular}

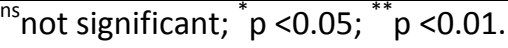

Similar results are presented by Fidelis et al. (2012) who obtained higher rice plant height in the cultivar BRS-MG Curinga by applying $120 \mathrm{~kg}$ $\mathrm{ha}^{-1}$ of $\mathrm{N}$. In addition to this result, the authors called attention to an important aspect, because high doses provide higher heights of rice plants, this can prolong the vegetative period, since $\mathrm{N}$ is abundant, prolonging the total crop cycle. In another paper, published by Cazetta et al. (2008), increases in height can also be observed at $\mathrm{N}$ rates ranging from 50 to $125 \mathrm{~kg} \mathrm{ha}^{-1}$.

$\mathrm{N}$ is an element that is directly associated with plant growth, so high doses may favor excessive growth when the environment is favorable. This can cause plant lodging, which makes harvesting difficult or even impracticable. In both agricultural years, lodging evaluations were made, but no treatment presented lodging.

Contrary to what happened, the hypothesis was that a higher dose of $\mathrm{N}$ would lead the rice plants to more plant lodging. One of the probable explanations is that $\mathrm{N}$ influences the growth and, consequently, the lodging of rice, depending on the cultivar, being some cultivars more resistant to lodging (CAZETTA et al., 2008), therefore, Mauad et al. (2013) states that for the cultivar IAC-202 increasing $\mathrm{N}$ doses also increase the lodging of rice plants.

Grain quality is an important requirement in rice cultivation as it is directly evaluated by the consumer. Grain chalkiness is an important characteristic for classifying rice grain in physical and industrial quality, since grain chalkiness are not desirable in the production chain, as consumers require translucent grains for consumption. For this characteristic, significant results were obtained for crop season, which had a superiority of non-chalkiness grains $(96,72 \%)$, of higher quality, in 2016/2017 crop season, when compared with result obtained in the 2015/2016 crop season (88\%).

Silva et al. (2013) share the results that increasing doses of $\mathrm{N}$ decrease the degree of grain chalkiness, besides decreasing the number of broken grains. Positive results were also found by Silva et al. (1987) which obtained a higher percentage of translucent grains with $\mathrm{N}$ applications in the cultivars IAC-435 and IR-665. However, in the present study, these differences were not observed between $\mathrm{N}$ doses.

Rice yield is the percentage of whole grains after resulting from the processing of 
paddy rice. The results of the joint yield analysis were significant for the sources of variation C.S and the interaction N.S x C.S (Table 1). In both sources of variation, the 2016/2017 crop season was over in yield when compared to the first crop, regardless of $\mathrm{N}$ source, which all sources showed better results for yield in the second crop season.

Table 2. Averages related to the analysis deployment crop season (C.S) between nitrogen source (N.S) for percentage of yield

\begin{tabular}{ccc}
\hline \multirow{2}{*}{ N source } & \multicolumn{2}{c}{ Crop Season } \\
\cline { 2 - 3 } & $2015 / 2016$ & $2016 / 2017$ \\
\hline Urea & $70,57 \mathrm{~b}$ & $72,13 \mathrm{a}$ \\
Ammonium Nitrate & $69,29 \mathrm{~b}$ & $73,36 \mathrm{a}$ \\
Ammonium Sulphate & $68,75 \mathrm{~b}$ & $73,04 \mathrm{a}$ \\
Polycote & $69,27 \mathrm{~b}$ & $73,36 \mathrm{a}$ \\
\hline
\end{tabular}

Averages followed by the same letter belong to the same group by the Scott and Knott test $(p<0.05)$.

It was also evaluated the 1000 grains weight, characteristic of the rice crop production components. In the joint analysis a significant result was obtained for N.F and crop season. Ammonium sulphate and polycote were the most responsive to the character (Table 3 ) and in the case of crop season, the second year was higher than the first year, indicating influence of the environment on this character (Table 4).

As in the present study, Cazetta et al. (2008) evaluating $N$ doses, found no significant difference for 1000 grains weight between the control $\left(0 \mathrm{~kg} \mathrm{ha}^{-1} \mathrm{~N}\right)$ and the applied doses, not even the highest, which was $125 \mathrm{~kg} \mathrm{ha}^{-1}$. The same result was found at $\mathrm{N}$ doses ranging from 0 to $150 \mathrm{~kg} \mathrm{ha}^{-1}$ by Buzetti et al. (2006). However, Fidelis et al. (2012) showed results that ranged from $1.3 \mathrm{~g}$ to $3.5 \mathrm{~g}$ for 1000 grains weight with the application of $120 \mathrm{~kg} \mathrm{ha}^{-1}$ of $\mathrm{N}$ in different rice cultivars.

Table 3. Averages related to the 1000 grains weight (g), according to the different $\mathrm{N}$ sources

\begin{tabular}{cc}
\hline N sources & Average \\
\hline Urea & $21,47 \mathrm{~b}$ \\
Ammonium Nitrate & $21,97 \mathrm{~b}$ \\
Ammonium Sulphate & $22,36 \mathrm{a}$ \\
Polycote & $22,84 \mathrm{a}$ \\
\hline
\end{tabular}

Averages followed by the same letter belong to the same group by the Scott and Knott test $(p<0.05)$.

Table 4. Averages related to the 1000 grains weight $(\mathrm{g})$, according to the crop seasons

\begin{tabular}{cc}
\hline Crop season & Average \\
\hline $15 / 16$ & $16,70 \mathrm{~b}$ \\
$16 / 17$ & $27,61 \mathrm{a}$ \\
\hline
\end{tabular}

Averages followed by the same letter belong to the same group by the Scott and Knott test $(p<0.05)$.

Regarding $\mathrm{N}$ sources, Hernandes et al. (2010) working wth Entec, ammonium sulfate and urea, did not observe distinct results in the 100 grains weight, different from the presented results, which the ammonium sulphate and polycote sources presented better averages for 1000 grains weight (Table 6).

Considering the grain yield characteristic, the joint analysis did not show any significant results at $5 \%$ for the grain yield character (Table 2 ), showing that the addition of different doses and nitrogen sources did not influence the grain yield of the cultivar used.

Fageria et al. (2007) demonstrated the importance of $\mathrm{N}$ in rice grain yield, also stating that the efficiency of $\mathrm{N}$ utilization varies among cultivars and that $\mathrm{N}$ influenced the number of fertile spikelets positively, thus helping the final increase of grain yield after $\mathrm{N}$ applications.

The difference in $\mathrm{N}$ utilization between cultivars may explain the non-significance of the results for grain yield in the present study, 
indicating that the absorption efficiency of cultivar CMG 1590 is always the same.

\section{Conclusions}

The different $\mathrm{N}$ doses and sources did not change the agronomic performance of the upland rice crop.

There is influence of the environment on the responses of plants to nitrogen application, being observed different results in different crop seasons.

\section{References}

BUZETTI, S. et al. Resposta de cultivares de arroz a doses de nitrogênio e do regulador de crescimento cloreto de clormequat. Pesquisa Agropecuária Brasileira, p.1731-1737, 2006. https://doi.org/10.1590/S0100$\underline{204 \times 2006001200007}$

CAZETTA, D.A. et al. Desempenho do arroz de terras altas com a aplicação de doses de nitrogênio e em sucessão às culturas de cobertura do solo em sistema de plantio direto. Bragantia, p.471-479, 2008. https://doi.org/10.1590/S0006-

\section{3}

EMBRAPA. Fertilização do solo. 2018. Disponível em:

http://www.agencia.cnptia.embrapa.br/gestor/ar roz/arvore/CONT000fessmgy502wx5eo0y53mhyv cjcebf.html. Acesso em: 17 jul. 2018.

EPSTEIN, E.; BLOOM, A.J. Nutrição mineral de plantas. Princípios e perspectivas. Londrina: Planta, 2006.

FAGERIA, N. K.; SANTOS, A. B.; CUTRIM, V. A. Yield and nitrogen use efficiency of lowland rice genotypes as influenced by nitrogen fertilization. Pesquisa Agropecuária Brasileira, v. 42, n. 7, p. 1029-1034, 2007.

FAOSTAT. Statistical databases. 2016. Disponível em: http://faostat.fao.org/site/339/default.aspx. Acesso em 10 set. 2019.

FERREIRA, D.F. Sisvar: a computerstatisticalanalysis system. Ciência e Agrotecnologia, Lavras, v. 35, n. 6, p. 1039-1042, $2011 . \quad$ https://doi.org/10.1590/S141370542011000600001
FIDELIS, R. R. et al. Eficiência do uso de nitrogênio em genótipos de arroz de terras altas. Pesquisa Agropecuária Tropical, v.42, n.1, 2012. https://doi.org/10.1590/S1983$\underline{40632012000100018}$

HERNANDES, A. et al. Doses, fontes e épocas de aplicação de nitrogênio em cultivares de arroz. Ciência e Agrotecnologia, p.307-312, 2010. https://doi.org/10.1590/S1413-

$\underline{70542010000200006}$

MAUAD, M.; COSTA, C.A.; GRASSI FILHO, C.H.; MACHADO, S.R. Deposição de sílica e teor de nitrogênio e silício em arroz. Semina: Ciências Agrárias, Londrina, v.34, n.4, p.1653-1662, 2013. https://doi.org/10.5433/1679$\underline{0359.2013 v 34 n 4 p 1653}$

MEDEIROS, R. D. et al. Resposta de cultivares de arroz irrigado a níveis de nitrogênio aplicados em cobertura no Estado de Roraima. In: CONGRESSO BRASILEIRO DE ARROZ IRRIGADO, 6., REUNIÃO DA CULTURA DO ARROZ IRRIGADO, 27., 2007, Porto Alegre. Anais [...]. Porto Alegre: Orium, 2007a. p. 617-618.

PIMENTEL-GOMES, F. Curso de estatística experimental. 15. ed. Piracicaba: FEALQ, 2009. $451 \mathrm{p}$.

SILVA, L.P. et al. Adubação nitrogenada sobre rendimento industrial e composição dos grãos de arroz irrigado. Ciência Rural, v.43, n.6, p.11281133, 2013. https://doi.org/10.1590/S0103$\underline{84782013005000055}$

SILVA, L.H.V.; FIGUEIRO, P.R.P.; VILLARROEL, A.B.S. Production of meat and wool by Corriedale lambs on native and cultivated pasture. Revista do Centro Ciências Rurais, v.17, p.283-293,1987.

SOUSA, D.M.G.; LOBATO, E.; REIN, T.A. Cerrado: correção do solo e adubação. 2. ed. Brasília: Embrapa Informação Tecnológica, 2004. p. 147167.

VILLAR, M.L.P. Manual de interpretação de análise de plantas e solos e recomendação de adubação. Cuiabá: EMPAER-MT, 2007. 182 p. 